Ms. Apoorva Singh

\title{
Human Rights and Women in Developing Countries
}

\author{
Ms. Apoorva Singh \\ Research Scholar \\ C.M.P Degree College, Prayagraj
}

\begin{abstract}
Human Rights refers to those rights which an individual enjoys by virtue of being human. Every individual is entitled to the benefits of these rights without any discrimination on grounds of religion, race, caste, sex, creed, or place of birth. Human Rights also guarantee certain freedoms to the holder of such rights. Such freedom could be Freedom of thought, freedom of speech, freedom of expression, freedom from slavery and torture, right to work, right to education, right against exploitation, right against discrimination, and many more.

The need and importance of recognizing these human rights were emphasized by the United Nations (UN). The UN Organization was formed in the year 1945 after the end of the Second world for to establish international peace and security and to promote and guarantee to all individuals basic human rights across the globe. To ensure proper recognition of these rights the UN formed a Universal Declaration of Human Rights in 1948. The declaration clearly stated some of the basic human rights which humans were entitled to enjoy. As above stated these rights extend to all individuals irrespective of the sex thus providing and extending the benefit of such rights to all the women across the globe. There is a common connotation that 'women rights are human rights' which is reflected in the UN Organization. Women are entitled to enjoy these rights and freedoms like other individuals. To ensure that these rights are provided to the women the organization formed various conventions to protect the rights of the women like Convention of all forms of discrimination against women, Convention on the Nationality of Married Women, Convention on the Political Rights of women to name a few.
\end{abstract}

Keywords: Human rights, Women's Rights, Violence against women, Gender equality, Feminist movement.

\author{
Reference to this paper \\ should be made as \\ follows: \\ Ms. Apoorva Singh \\ Human Rights and \\ Women in Developing \\ Countries \\ Journal Global Values \\ Vol. XI, No.I \\ Article No.14 \\ pp. 114-119 \\ http://anubooks.com/ \\ ?page_id $=6195$ \\ https://doi.org/ \\ 10.31995/ \\ jgv.2020.v11i01.014
}




\section{Introduction}

Human Rights are the basic rights and freedoms that belong to every person in the world, from birth until death. They apply irrespective of the place where one comes from, what one believes in, or how one chooses to live his or her life. They may be restricted in the interests of national security at any point in time but can never be taken away. They are based on values like dignity, fairness, equality, respect, and independence. Since they are not merely abstract concepts, they have to be defined and protected by law. At the universal level, after its formation in 1945, the United Nations took upon itself the responsibility to define, establish, and safeguard the basic principles of human rights vide international agreements and treaties. The Universal Declaration of Human Rights, 1948 is the foundation for modern human rights. The declaration recognizes that 'all human beings are born with equal and inalienable rights and fundamental rights', such as the right to life, freedom from torture, inhuman or degrading treatment. As the UN charter enshrines "equal rights of men and women", protection and promotion of women's human right is the responsibility of all the states.

Women's rights are the rights and entitlements claimed for women and girls of many societies across the globe and which formed the basis for the women's rights movement during the nineteenth century and feminist movement during the $20^{\text {th }}$ century. Issues that are commonly associated with notions of women's rights include, though are not limited to, the right to bodily integrity and autonomy; to be free from sexual violence; to vote; to hold public office; to enter into legal contracts, to have equal rights in family law; to work; to fair wages or equal pay; to have reproductive rights; to own property and to education. However, despite such provisions becoming international law, millions of women around the world continue to experience discrimination:

- Laws and policies prohibit women from equal access to land, property, and housing

- Economic and social discrimination results in fewer and poorer life choices for women, rendering them vulnerable to trafficking

- Gender-based violence affects at least $30 \%$ of women globally

- Women are denied their sexual and reproductive health rights

- Women human rights defenders are ostracized by their communities and seen as a threat to religion, honor or culture

- Women's crucial role in peace and security is often overlooked, as are the particular risks they face in conflict situations 
Human Rights and Women in Developing Countries

Ms. Apoorva Singh

Moreover, some groups of women face compounded forms of discrimination due to factors such as their age, ethnicity, disability, or socio-economic status, in addition to their gender.

Effectively ensuring women's human rights requires, firstly, a comprehensive understanding of the social structures and power relations that frame not only laws and politics but also the economy, social dynamics, and family and community life.

Harmful gender stereotypes must be dismantled, so that women are no longer viewed in the light of what women "should" do and are instead seen for who they are: unique individuals, with their own needs and desires.

Discrimination based on sex is prohibited under almost every human rights treaty- including the International Covenant on Civil and Political Rights ${ }^{1}$ and the International Covenant on Economic, Social and Cultural Rights ${ }^{2}$, which under their common article 3 provide for the rights to equality between men and women in the enjoyment of all rights.

There are treaties and expert bodies specifically dedicated to the realization of women's human rights:

\section{The Convention on the Elimination of Discrimination Against Women (CEDAW)}

Considered the international bill of rights for women, the Convention defines what constitutes discrimination against women and sets an agenda for national action to end such discrimination. It was adopted by the United Nations in 1979 and came into force on 3 September 1981. The convention defines the right of women to be free from discrimination and sets the core principles to protect this right. It estasblishes an agenda for national action to end discrimination and provide the basis for achieving equality between men and women's through ensuring women's equal access to, and equal opportunities in, political and public life as well as education, health, and employment. CEDAW is the only human rights treaty that affirms the reproductive rights of women. ${ }^{3}$ The convention has been ratified by 189 states $^{4}$, making it one of the most ratified international treaties. Countries that are parties to the Convention must submit periodic reports detailing their compliance with its provisions every four years. The Committee reviews those reports and may also hear claims of violations and inquire into situations of grave or systemic contraventions of women's rights.

In 1994 the United Nations resolved to appoint a Special Rapporteur - an independent expert- on the causes and consequences of violence against women. The Special Rapporteur investigates and monitors violence against women, and recommends and promotes solutions for its elimination. The mandate was extended by the 
Commission on Human Rights in 2003, at its 59th session in resolution 2003/45.

Despite great strides made by the international women's rights movement over many years, women and girls around the world are still married as children or trafficked into forced labor and sex slavery. They are refused access to education and political participation, and some are trapped in conflicts where rape is perpetrated as a weapon of war. Around the world, deaths related to pregnancy and childbirth are needlessly high, and women are prevented from making deeply personal choices in their private lives. Human Rights Watch is working toward the realization of women's empowerment and gender equality-protecting the rights and improving the lives of women and girls on the ground.

Despite many successes in empowering women, numerous issues still exist in all areas of life, ranging from the cultural, political to the economic. For example, women often work more than men, yet are paid less; gender discrimination affects girls and women throughout their lifetime; and women and girls are often are the ones that suffer the most poverty.

Reading the report about the United Nation's Women's Treaty and how a variety of countries have lodged reservations to various parts of it shows we still have a long way to go to achieve universal gender equality.

Gender equality furthers the cause of child survival and development for all of society, so the importance of women's rights and gender equality should not be underestimated.

It isn't easy to change tradition overnight. However, a small example of successes include:

- The gains made in South Africa

- Childhood concerns in Latin America

- Poor women gaining greater access to savings and credit mechanisms worldwide, due to microcredit.

- A dwindling number of countries that do not allow women to vote including Bhutan (one vote per house), Lebanon (partial), Brunei (no-one can vote), and the Vatican City.

- Women gaining more positions in parliament throughout Africa. In many cases, African countries have more women in parliament than some western ones.

- A protocol to protect women's rights in Africa (though many nations still need to sign up).

- An almost universal ratification of the women's rights treaty, the Convention 
Human Rights and Women in Developing Countries

Ms. Apoorva Singh

on the Elimination of All Forms of Discrimination against Women (CEDAW) On the 30th anniversary of CEDAW Inter Press Service (IPS) listed several benefits the women's right treaty has provided around the world, for example:

- Morocco gave women greater equality and protection of their human rights within marriage and divorce by passing a new family code

- India has accepted legal obligations to eliminate discrimination against women and outlawed sexual harassment in the workplace

- In Cameroon, the Convention is applied in local courts and groundbreaking decisions on gender equality are being made by the country's high courts

- Mexico passed a law toughening its laws on violence against women

- CEDAW committee in Austria decided two complaints against Austria concerning domestic violence

- Former UN Secretary-General Ban Ki-moon also noted that within the UN itself, the number of women in senior posts has increased by 40 percent

- "The Convention has been used to challenge discriminatory laws, interpret ambiguous provisions or where the law is silent, to confer rights on women," Navi Pillay, U.N. High Commissioner for Human Rights, said.

Years after the adoption of the Convention on the Elimination of All Forms of Discrimination against Women (CEDAW), many girls and women still do not have equal opportunities to realize rights recognized by law. In many countries, women are not entitled to own property or inherit the land. Social exclusion, "honor" killings, female genital mutilation, trafficking, restricted mobility, and early marriage among others, deny the right to health to women and girls and increase illness and death throughout the life-course. We will not see sustainable progress unless we fix failures in health systems and society so that girls and women enjoy equal access to health information and services, education, employment, and political positions.

\section{References}

1 United Nations Treaty Collection available at https://reaties.un.org/Pages/ ViewDetails.aspx?src=TREATY\&mtdsg_no $=\mathrm{IV}-8 \&$ chapter $=4 \&$ lang $=$ en

2 Convention on the Elimination of All Forms of Discrimination against Women 1979 available at https://www.un.org/womenwatch/daw/cedaw/

3 Convention on the Elimination of All Forms of Discrimination Against Women (CEDAW) for Youth available at https://www.unwomen.org/en/digitallibrary/publications/2016/12/cedaw-for-youth

4 Convention on the Elimination of All Forms of Discrimination against Women, Inter Press Service News Agency available at http://www.ipsnews.net/topics/ 
convention-on-the-elimination-of-discrimination-against-women-cedaw/

5 Convention on the Elimination of All Forms of Discrimination against Women New York, 18 December 1979, United Nations Human Rights Office of the High Commissioner available at https://www.ohchr.org/en/ professionalinterest/pages/cedaw.aspx

\section{(Footnotes)}

1 Adopted by the General Assembly of the United Nations on 19 December 1966.

2 A multilateral treaty adopted by the United Nations General Assembly on 16 December 1966.

3 Article 16, 10 Convention on the Elimination of All Forms of Discrimination against Women 1979.

4 United Nations Treaty Collection available at https://treaties.un.org/Pages/ ViewDetails.aspx $?$ src $=$ TREATY \&mtdsg_no $=I V-8 \&$ chapter $=4 \&$ lang $=$ en 